\title{
Standardization of Business Processes in the Transportation Sector
}

\author{
Drachuk Yurii ${ }^{1}$, Trushkina Nataliia ${ }^{2}$, Serhieieva Olena ${ }^{3}$, Snitko Yelyzaveta ${ }^{4}$, \\ Belyaeva Ganna ${ }^{5}$
}

\author{
${ }^{1}$ Department of Problems of Perspective Development of the Fuel and Energy Complex, Institute of Economics Industry of the \\ National Academy of Sciences of Ukraine, Kyiv, Ukraine \\ ${ }^{2}$ Department of Regulatory Policy and Entrepreneurship Development, Institute of Industrial Economics of NAS of Ukraine, Kyiv, \\ Ukraine \\ ${ }^{3}$ Department of International Trade, Alfred Nobel University, Dnipro, Ukraine \\ ${ }^{4}$ Department of Management, Lugansk National Taras University Shevchenko, Starobelsk, Ukraine \\ ${ }^{5}$ Department of Entrepreneurship, Odessa National Maritime University, Odessa, Ukraine \\ Email: drachuk.yuriy@gmail.com, nata_tru@ukr.net, sergeyeva.1966@gmail.com, esnitko@gmail.com, bel.ann44@gmail.com
}

How to cite this paper: Yurii, D., Nataliia, T., Olena, S., Yelyzaveta, S., \& Ganna, B. (2021). Standardization of Business Processes in the Transportation Sector. Open Journal of Business and Management, 9, 2312-2328. https://doi.org/10.4236/ojbm.2021.95125

Received: August 17, 2021

Accepted: September 11, 2021

Published: September 14, 2021

Copyright $\odot 2021$ by author(s) and Scientific Research Publishing Inc. This work is licensed under the Creative Commons Attribution International License (CC BY 4.0).

http://creativecommons.org/licenses/by/4.0/

\begin{abstract}
The paper focuses on determining the aspects of the approach to business processes optimization at transport enterprises in modern economic conditions based on the generalization of their standards, according to which the process principle of enterprise management organization is considered more effective. The process approach is focused primarily on business processes, the ultimate goals of which are to create products or services that are of value to external or internal consumers. A significant number of experts from different industries participate in the creation of a complex standards process. Standardization concerns many topics in the transport industry, higher education, logistics business, and performs similar functions. Standardization will help to increase the country's transport potential. Standardized processes in the industry will contribute to obtaining a positive effect on the quality of customer service, increasing the competence of personnel, as well as optimizing work processes leading to the increased financial results of enterprises.
\end{abstract}

\section{Keywords}

Standardization, Process Approach, Service Quality, Consumers, Transport Industry, Competence, Personnel

\section{Introduction}

As noted in the National Transport Strategy of Ukraine 2030, the transportation 
industry is one of the basic sectors of the economy, which includes an extensive railway network, a developed network of highways, seaports and river terminals, airports and a wide network of air routes, cargo customs, and in such way creates the prerequisites necessary for meeting the demands of transport users concerning provision of transport services and business development. According to the National Transport Strategy of Ukraine until 2030 (2021), "it is necessary to increase the efficiency and competitiveness of the transport industry, improve the legal framework of public-private partnership, strengthen interaction between the public and private sectors, public authorities and local self-government bodies, carry out the necessary reforms, including the introduction of decentralization, especially through coordinated public policy initiatives. These principles will provide a solid foundation for the sustainable development of the transport industry and the creation of a free and competitive transport services market".

The purpose of the work is to determine the aspects of the approach to the optimization of business processes at transport enterprises in modern economic conditions based on the generalization of their standards.

\section{Methods}

The methodological basis of the research is the scientific works of foreign and Ukrainian scientists on the green economy, logistics, management, marketing, information technology.

The study was carried out using general scientific methods: analysis and synthesis, classification, statistical analysis and comparison, structural and logical generalization, a systematic approach.

\section{Results}

The researchers note that, "Signs of the modern economic environment in the transport industry are the increased competition between national and foreign transport corporations, the emergence of a new type of risk in the cargo transportation businesses, which have both economic and social nature; recurrent market fluctuations, which affect the speed and direction of cargo transportation by sea" (Belyaeva \& Drachuk, 2018).

In the conditions of the modern changing environment of the enterprise, the process principle of the organization of enterprise management is considered more effective and the most progressive from the point of view of competitiveness. In accordance with this approach managers focus on the interaction of process participants, which due to uncertainty, leads them directly to economic losses. And the process approach is focused primarily on business processes, the ultimate goals of which are to provide products or services that are of value to external or internal consumers. In order to manage business processes effectively, constantly improve and optimize them, the following main indicators are improved: cost reduction, quality improvement, efficiency, satisfaction of con- 
sumers and employees; the quality and efficiency of the enterprise management system. Apart from that innovation is accelerated; investment interest is increased; personnel development and reproduction of labor potential, adaptation of the enterprise to the conditions of an ever-changing external environment is ensured (Belyaeva \& Drachuk, 2018).

The European Union (EU) has a powerful intellectual and technological potential, which continues to move towards creating a competitive, dynamic economy based on knowledge-an effective catalyst for the innovative development of the EU countries in the long term course. Innovation policy has acquired a comprehensive, systemic and long-term character with clearly defined quantitative and qualitative guidelines, and the EU common policy acts as a "locomotive" for national governments and private business, which focus on the creation of an innovation union and the introduction of appropriate mechanisms for innovative interaction between science and business, new methods and forms of initiating innovative processes, methods and forms of communication of business entities (Sav'yuk \& Drachuk, 2018).

"In the socio-economic system, innovation is defined as a way to use resources more efficiently. Due to the complex expansion of innovation, a new technological and socio-economic subsystem of society is formed, consisting of industries that create innovations; industries that disseminate new technologies and deepen their economic advantages; industries that arise as a result of the development of a new technological order" (Amosha et al., 2017).

According to the researchers, "Creating standards is a difficult and complex process carried out by a significant number of specialists from different industries. Standardization concerns many topics in the field of higher education, logistics business, performs similar functions: freight-forwarding, the activities of port terminal operators, organization of transport, storage, route development taking into account the specifics of the order, congestion and the type of vehicle used" (Belyaeva et al., 2020).

Due to the intensive spread of logistics operations in the activities of enterprises, primarily in the service sector and in many forms of non-production communications, there is a need for unification, standardization, so that one "professional language" is used in the professional logistics environment. Thus, the technical committee for standardization "Logistics, freight-forwarding and supply chain Management" is being created (the SE "UkrNDNC" order No. 3 of January 17, 2017). At the initial stage, the program provides for the processing of EN and ISO standards related to logistics and the creation of a dictionary of terms (Krikavskij, 2017).

The logistics sector is dynamically developing on account of the introduction of technologies. The winner is the company that responds to changes in a timely manner and optimizes business processes using modern IT technologies, thereby increasing the speed of delivery, whereas the prime costs decrease due to reduced production costs and operation time. 
All this requires the introduction of a complex of various logistics information technologies, which can include (Trushkina, Drachuk, \& Zaloznova, 2016; Zaloznova \& Trushkina, 2018a; Zaloznova \& Trushkina, 2018b; Tryfonova \& Trushkina, 2019; Trushkina, 2019a; Trushkina \& Rynkevych, 2019; Sandiuk et al., 2019; Koev et al., 2019):

MRP (Material Requirements Planning) - allows optimal regulation delivery of components to the production process, controlling stocks in warehouse and production technology. The main task is to provide a guarantee of the availability of the required number of relevant materials and components at any time within the planning period along with possible reduction of permanent stocks;

ERP (Enterprise Resource Planning System) - expands the range of supply chain management beyond the enterprise, allows you to control and regulate communications between the supply chain members. Oriented on processes and internal integration (logistic and financial);

OPT (Optimized Production Technology) - the basic principle is to identify "bottlenecks" on production or critical resources (stocks of raw materials, materials, equipment). Solved the tasks of operational and short-term management of production, including the formation of a production schedule on one day, week, etc.;

SCM (Supply Chain Management) - the integration of key business processes from begins the end-user and covering all suppliers of goods, services, and products that add value for consumers and other stakeholders. This is a technology that ensures the corporate strategy of an enterprise with the optimal cost of resources. It allows you to solve the tasks of integrated management of functional areas and coordinate the logistics process of enterprise with business partners depending on the electronic platform (B2B or B2C);

CRM (Customer Relationship Management)-information technologies that implement a client-oriented approach to the management of the enterprise. The essence of this system consists of personalization of relations with clients, achieving a favorable attitude of clients to the enterprise and products, understanding the process of sale as a permanent process with the involvement of each employee of the enterprise;

QR (concept "Quickly Reaction")-Quick customer service that is used to manage the movement of goods with a short life cycle. It is a system of service delivery end-customer based on the electronic data exchange between retailers and wholesalers and manufacturing areas;

ECR (system organization of economic relations the producer's products and trade enterprises) - this system is based on the principle of JIT and is based on the exact synchronization of production and sales, which involves a specific approach to control the state of stocks and reorganization of the functions of distribution centers. Used the principle of continuous replenishment of stocks, according to which extended of powers the suppliers in order to provide the necessary amount of supply and delivery terms; 
LP (concept "Lean Production") - realized the idea of combining low cost with large volumes of mass production and product diversity and the flexibility of small-scale production. The main idea is to identify operations that consume resources, but do not create added value and their complete elimination;

DDT (concept "Demand Reaction") — it allows to maximize the response time reaction of enterprise to change demand through the rapid replenishment of stocks at those points of the market where predicted the growth of such demand, improves the coordination and relationship of producers, intermediaries, and retailers as links to the integrated logistics chain;

DRP (planning system of products and resources in distribution) - DRP I allows not only to take into account conjuncture but also to actively influence it. This system ensures stable ties supply, production, and sales. The ultimate function of the DRP I system-planning transport traffics. In the system processed requests for transport services, drawn up and adjusted in real-time the scheduled traffic. Due to the DRP II technology is solved the tasks of medium to long-term forecasting of consumer demand, indicators system of work of warehouses and other parameters;

CALS-technologies-integrated system strategy for increasing the efficiency, productivity, and profitability of processes production-economic activity the enterprise, which directly influences on the competitiveness of its products. The task of this technology is to increase the efficiency of all participants in the process of creation, production, and use of the product by expediting the process research and development of the product; providing the product of new properties; cost reduction; increase the level of service in the processes of production the product, its operation, and technical maintenance.

The use of information and digital technologies will increase the efficiency of logistics management by obtaining the synergistic effect due to increasing average profitability from the organization of logistics activities by $15 \%-20 \%$; increasing of indicator the consumer retention by $5 \%$; time reduction on performing current operations by $25 \%$ - 30\%; increasing the accuracy of forecasting volumes of shipment products up to $99 \%$; reduction of costs on sales, marketing and customer support by $10 \%-15 \%$; increasing the speed of customer orders processing and level information security; reduction of time losses on organization exchange of information between the enterprise and economic contractors; formation of client-oriented approach to the management of relations with different groups of consumers the enterprise (Zaloznova \& Trushkina, 2019).

For example online platform "Shipnext" taking place on the sea transportation market allows you to make transportation fast, transparent and cost-effective. Standardization and search for the optimal delivery scheme and calculation of the transportation costs is a complex process that requires work in different time zones, with a huge amount of data. This program allows you to integrate various aspects and sectors of the market. This online platform is designed so as to operate all types of cargo, conduct tenders and negotiations, manage contracts, re- 
porting, post-fixations, as well as user ratings.

In order to optimize the company's internal business processes, it is important to understand how they are being performed at the moment and what changes are necessary. Business process automation allows you to take a critical look at the process and immediately eliminate duplication of functions, simplify the execution of complex operations and automate routine actions.

According to logistics experts, modern programs design and development, including those used in the transport industry, reduce the volume of direct labor, the number and duration of routine actions. This contributes to the reduction of jobs and creates an environment for the in-depth development of the so-called "soft skills" of employees. Thereby "soft skills" are becoming very relevant in our time and represent a certain list that enumerates behavior patterns being helpful for people in their work, particularly in team work. These are interprofessional and universal skills that are useful for any type of activity, allowing to quickly adapt to new conditions, change the field of employment, and come up with out-of-box solutions. Highly specialized skills- "hard skills" are effective for solving typical tasks specific to some field, they operate within a specific profession, in constant conditions and formalized work process, turning mostly automated.

Thus, the standardization of the most developed sectors of the logistics market (warehouse, transport, postal, courier) will help to increase the transport potential of the country. Standardized processes in the industry contribute to obtaining a positive effect on the quality of customer service, increasing the competence of personnel, and also optimize work processes, resulting in the increasing financial results of enterprises.

"The realities of the current stage of the implementation of European integration processes require finding solutions to a number of priority problems in strategic areas of the economy, such as transport. The main task for carriers is not only to maintain and consolidate their positions in the transport services market, but also to increase production and economic potential, the effectiveness of all types of activities through continuous improvement of integrated services" (Andrienko \& Syuechen, 2020).

In the market conditions of complex interaction among all participants of the transport market, the overall reduction in traffic volumes and the growth of competition of some types of transport, the main goal is to provide fast and high-quality customer service, gradually introduce new transportation technologies. Taking into account consumers' interests as much as possible and ensuring the competitiveness of both the economic entities themselves and the services of transport companies, transport enterprises require the use of a whole set of scientifically based principles.

According to the researchers, "the system of business processes standardization is one of the main factors ensuring the competitiveness of products and services in the developed countries. In order to integrate into the global market, it is 
necessary to work according to its rules not only in terms of production technology, but also in the management system of the entire enterprise. The development, implementation and certification of a management system at an enterprise is not only increasingly becoming a requirement of customers, but also turning into a tool for internal processes optimization. This contributes to the quality improvement of products and services, production costs reduction, and increase of the activities profitability. Business processes standardization allows to define clearly interrelated and interacting processes, identify correctly and achieve the established measurable goals of activity. The internal results that an enterprise receives from the implementation of a process management system depend on the efforts that are taken to improve the activities. The company receives external advantages by certifying its management system in an independent competent certification body. Standardization accompanies the enterprise throughout its life cycle and is a non-tariff form of regulation" (Horohov, 2017).

It should be emphasized that the change of the modern paradigm of thinking and approaches to standardization requires the reorganization of logistics processes and the need to transform transport and logistics systems in the context of the concepts of green economy and balanced sustainable development (Trushkina, 2019b; Trushkina, 2019c; Hryhorak \& Trushkina, 2020; Dźwigoł, Kwilinski, \& Trushkina, 2021; Dźwigoł, Trushkina, \& Kwilinski, 2021).

This is due to the fact that the field of transport and logistics, on the one hand, has a negative impact on the environment (third in the world in terms of carbon dioxide emissions), and, on the other has significant potential for the model of "green" growth.

A survey conducted in 2019 by the consulting company PwC found that $41 \%$ of managers of transport and logistics companies in 85 countries are concerned about climate change and environmental damage associated with the growth prospects of their business.

The World Economic Forum has established that greenhouse gas emissions from logistics account for 5.5\% of global greenhouse gas emissions. According to UN estimates, the global transport sector generates $25 \%$ of total greenhouse gas emissions. Annually, the total loss from the negative effects of the transport industry is $7 \%-10 \%$ of GDP. The damage to health caused by environmental pollution from mobile sources is 1 trillion dollars USA per year. According to official Eurostat data, air pollution from road transport causes more than 400,000 premature deaths each year.

Therefore, large-scale investment programs are being actively implemented in the European Union in order to modernize transport and infrastructure by "greening" them in order to minimize the negative impact on the environment and maintain a competitive position. Such programs are usually based on the technologies of the third and fourth industrial revolutions. Significant advantages of the third industrial revolution include the "greening" of transport systems 
through the transition to hydrogen and electric transport, which contributes to a dramatic improvement in the quality of the environment. For example, the EU Transport Strategy envisages a reduction of greenhouse gas emissions by approximately $20 \%$ from their level in 2008, and in general by 2050 -by $80 \%-95 \%$ below the level of 1990.

In addition, the European Commission supports the transition to sustainable mobility through the Connecting Europe Facility financial mechanism. The Fund allocates approximately $60 \%$ of its budget to infrastructure projects that aim to achieve sustainable development and play an important role in creating a European network of alternative fuel tariffs and a highly productive and efficient combined transport system.

It should be noted that the modernization of transport and logistics systems of various levels in Ukraine should be carried out within the framework of the European transport policy TEN-T, aimed primarily at rational use of resources and reduction of greenhouse gas emissions. This corresponds to the main provisions of Chapter 7 "Transport" of the Association Agreement between Ukraine and the EU, the Sustainable Development Goals of Ukraine until 2030 (creation of sustainable infrastructure), the State Strategy for Regional Development until 2027 (formation of a cohesive country in social, economic, ecological and spatial dimensions).

According to the National Transport Strategy of Ukraine for the period up to 2030 , it is necessary to take into account such a global trend of transport development as the use of "green" modes of transport, the priority of environmental protection, and preservation of valuable protected areas during transport infrastructure development. The strategy plans to reduce greenhouse gas emissions from mobile sources to $60 \%$ of 1990 levels.

Given this, it is advisable to search for innovative tools and scientifically sound "green" solutions, as well as the introduction of fundamentally new organizational and managerial approaches and "green" technologies to improve the efficiency of the transport sector in Ukraine.

In the scientific literature, there are many approaches to the consideration of the environmental component of logistics (Janbo \& Songxian, 2008; Brdulak \& Michniewska, 2009; Sbihi \& Eglese, 2009; McKinnon et al., 2010; Mesjasz-Lech, 2011; Ubeda, Arcelus, \& Faulin, 2011; Christof \& Ehrhart, 2012; Lai \& Wong, 2012; Dekker, Bloemhof, \& Mallidis, 2012; Ćirović, Pamučar, \& Božanić, 2014; Harris, Mumford, \& Naim, 2014; Jedliński, 2014; Seroka-Stolka, 2014; Zhang et al., 2015). The greening of logistics is recognized as a key driver of business development, as most consumers prioritize those companies that carry out freight transportation by "green" transport and use technologies that conserve natural resources.

Based on the analysis conducted by the consulting company PwC PESTEL, it is established that the emphasis on environmental sustainability and stringency of emission standards will force transport and logistics companies to move to 
environmentally friendly and safe decisions, i.e. to "green" logistics. Climate change is expected to continue to affect meteorological phenomena, leading to the destabilization of supply chains. Reducing the stocks of natural resources will lead to higher prices for them and will promote the processing and more efficient allocation of resources. As a result, sustainable and environmental development issues will be in high demand in the long run for the development of infrastructure project management standards.

From the management practice-today there is a significant number of project management standards. So, the researcher T. Silchuk understands the project management standard as a methodology aimed at optimizing the project processes and creating conditions for the implementation of the project according to the work plan. It is quite obvious that different standards include different technology. Thus, the main ISO technology is quality management, ORM3-assessment and development of the organization's capabilities, IRMA-development of project competencies (technical, behavioral, contextual), P2M-on the "iron" triangle of contextual constraints (Sil'chuk, 2014).

Based on the studies of the papers, it was found that the following world project management standards are used in Ukraine: $\mathrm{PMBoK}^{\circledR}$ (A Guide to the Project Management Body of Knowledge), PRINCE 2 (Projects in Controlled Environments), P2M (Project and Program Management for Enterprise Innovation), ISO 10006 (Quality management systems-Guidelines for quality management in projects). Among the project management standards in Ukraine, the most common are: IPMA (Competence Baseline Version 2.0), ISO 9000, P2M, CP3M (ORM3). All of them according to project management standards do not have a rigid specification and, depending on their essence, can be used in the practical activities of any enterprise. However, each type of activity has different features.

The works of A. Braginsky, V. Kovalev, A. Matiyko, A. Sobkevich, A. Khaletskaya are devoted to the role of transport infrastructure in improving the transportation process. Thus, according to the work of A. Khaletska (2015), “The relevance of the study of transport support is evidenced by the attempt of our state to integrate into the European community, which sets new requirements for transport infrastructure. All this actualizes the need to apply a systematic approach to improve state regulation of transport support in the direction of simplifying foreign trade procedures". As the author notes, the improvement of state regulation of transport support should be carried out according to clearly defined principles to ensure a systematic direction of movement and modernization of the industry. And taking into account the pan-European priorities, transparency, simplification, harmonization, standardization should become the basic principles for improving state regulation of the transport support development. And an important area of research in the transportation field should be the development of standards for the provision of transport services and mechanisms for their implementation. 
Today, the basis for a competitive enterprise, as noted in the article (Yakimishin, 2015), is "innovations that primarily affect the increase in customer satisfaction, which is related to the provision of a wider range of product elements, the use of modern technologies and the formation of an organization in the form of a supply chain. Therefore, it is advisable to restructure business processes in the supply chain in the context of outsourcing from the angle of efficiency and competitiveness increase, that are influenced by such factors as economies of scale, the "experience curve effect", the cost of acquiring key resources, connections with other activities in the chain, the exchange of opportunities between participants, the advantage of being the first in the market, the share of fixed costs in the total amount of expenses, the overall strategy and speed of operational decisions."

In a competitive environment, an enterprise can be truly effective only if it manages to attract its customers and suppliers to integration. This external integration determines the supply chain, in which, in the long term, successes or failures affect each of its participants, therefore, the problem of establishing partnerships between consumers and suppliers is actualized. The subject of outsourcing can be any business process (Business Process Outsourcing-BPO). Outsourcing as a project for the reconstruction of business processes at an enterprise should be a long-term strategic process. When it comes to outsourcing concept the starting point is to decide how to "make" or "buy". The decision to "buy" is increasingly being made due to the influence of many factors. First, there is a constant increase in the number of firms providing outsourcing services, and their capabilities are increasing. Currently, they are involved in almost all aspects of the economic activities of enterprises. With each new client, the level of knowledge and capabilities of service providers increases. In the end, the outsourcing market is developing and will soon reach such a level of saturation that outsourcers will be able to accept any types of economic activities of the client enterprise for execution. Another factor in favor of "buy" is technologies that today have a short life cycle, and from an innovative point of view are rapidly aging. Internal investments in technologies are becoming so risky that it is safer for an enterprise to purchase services. Using outsourcing, an enterprise can focus on the main business, which determines its competitive advantages and creates opportunities for development.

According to the work (Shulyar, 2019), quite useful is the provision, regarding "the formation of method maps for managing the quality of business processes of enterprises in order to ensure the flexibility and adaptability of quality management systems, which include the economic and managerial tools for ensuring business processes in the enterprise management system that represent a necessary arsenal of methods for maintaining the flexibility, adaptability and quality of business processes. Such tools are needed to timely recognize the harmful influence of the environment at the enterprise, overcome deviations in qualitative and quantitative indicators of the flow and effectiveness of business processes. It 
is business processes themselves that set the task to better and more accurately track the features of their operation, using monitoring, current control of quality indicators, viewing and comparing basic business process models based on the concept of benchmarking, systematic optimization of management decisions in the quality management system, ranking of business processes, importance in terms of vertical integration, creation of competitive environment at the entrance of business processes, flexible management and quantitative parameters." As noted by the author of the work (Yakimishin, 2015), the economic and managerial tools for ensuring business processes in the enterprise management system represent a necessary arsenal of methods for maintaining the flexibility, adaptability and quality of business processes.

But not every process carried out at the enterprise can be called a business process, even if this process leads to the creation of a product, and is of value to the consumer. As noted in the work of V. V. Demidenko (2015), "a distinctive feature of the business process is its business orientation, a certain direction of economic activity for making a profit." An enterprise can have a number of key business processes, the implementation of which determines their success in the market. As noted in the article (Demidenko, 2015), the following basic categories are taken as the basis for the business processes classification: basic business processes; supporting business processes; managerial business processes; business development processes. And the main business processes are those processes that are focused on the production of goods or the provision of services that are of value to the client, and provide income for the enterprise. The identification and classification of business processes of a particular enterprise, the determination of their parameters is a complex task that must be performed while implementation of a process approach to the organization and management of the enterprise's activities. One of the methods of describing business processes and business organization technologies, which is based on the process approach and corporate information systems, is proposed by researchers known as the Workflow method, that is, "work flow", automation of enterprise business processes, which is part of the Business process Management concept (Business Process Management, BPM). Workflow is currently considered a key technology that influences the development of other technologies. Workflow (according to the glossary of the Workflow Management Coalition, an international organization engaged in the introduction of standards in Workflow systems) is a time-ordered series of work tasks designed to be received and performed by employees in sequences defined for a given business process. The Workflow technology in the world emerged as the result of a gradual transition from a functional-oriented organization to a process-oriented one. At the same time, the main focus is made on individual business functions, as on the process itself. From the world practice, the introduction of such a technology significantly reduces the duration of working cycles and allows you to minimize the response time to customer requests and to change the situation on the market. 
Today, Workflow technology is considered to be the basis of the business organization model and corporate information systems of the twentieth century. It is perfectly suited to the domestic business conditions, the main of which are the unpredictability of market development and the external environment.

The most important feature of Workflow technology is the support for managing processes that contain both automated-performed by means of information systems, and non-automated-manually performed operations. Due to this feature, any business process of an enterprise can be represented as a Workflow process, if, of course, this process is: highlighted; or structured; performed according to rules, can be formulated; or occasionally repeated. The first three constraints are the answer to the question "which processes can be described", and the last one is "which are appropriate". The implementation of the Workflow class system is based on the description of the business process, for the effective implementation of which, in fact, the routing of documents and/or automation of operations is carried out.

The use of Workflow technology, as noted by experts and researchers, allows the company to obtain a number of competitive advantages, including:

- continuous monitoring and change management;

- quality management of both products and workflow;

- continuous constant exchange of information;

- effective decision-making support;

- identification of hidden problems;

- providing communication between technologies and people by organizing all the main components of the business process -

- the ability to use the Internet for direct active interaction with customers, suppliers and partners;

- strengthening control over the performance of tasks related to information processing;

- providing enterprise analysts with statistics for analyzing workloads, expenses, peak load periods and many other aspects of activity;

- modeling of procedures and possible scenarios of their implementation high-detailed and accurate.

The role and importance of business processes of industrial enterprises in the new economy is noted in the monograph by Polinkevich A. (2014), where the author defines the business process as a stable, purposeful set of interrelated activities that use a certain technology to transform inputs and outputs that are of value to the consumer. As the author notes, "business processes are an integral part of the enterprise, the results of which form the overall competitiveness and innovative ability of an industrial enterprise. Therefore, effective management of them is crucial from the point of view of the production process establishment in accordance with European standards and the requirements of ISO 9000 series. In the new economy, based on a simple mechanism for adapting business processes to the new economy, there are a number of features for developing a policy for 
managing them. The mechanisms of business processes management of industrial enterprises are a set of interrelated structural elements that determine the activity of the enterprise, ensuring rapid adaptation to the new economy."

Market economic conditions require many enterprises to conduct their business most efficiently, reducing operating costs while maintaining high quality of goods and services. And it is important in modern conditions to choose a model for the functioning of auxiliary business processes, which contributed to its innovative development and ensured the competitiveness of products on the domestic and international markets.

\section{Conclusion}

It is very difficult to ensure an adequate effective response to rapid changes and implement appropriate measures in the organization and implementation of entrepreneurial activities in a changing business environment. The process approach to management, which remains the most competitive for the enterprise, is considered more effective in this process. The business process in the process approach is a planned algorithm of interrelated actions or work flows that is subject to systematic changes under the influence of external and internal environmental factors and is aimed at meeting consumer demand and maximizing profit. This process has a beginning, a certain number of active stages and the result of work. Moreover, an enterprise can have a number of different business processes that are grouped into the main ones, providing management and business development processes. One of the modern methods of describing business processes and technologies of business organization and corporate information systems, proposed by researchers, is Workflow, the implementation of which allows you to streamline the activities of enterprises, increase the efficiency of their economic activities and competitiveness.

To increase the efficiency of management of logistics activities of economic entities, optimization of transport flows, improvement of the procedure of standardization of business processes in Ukraine, it is advisable to develop a set of strategic measures for:

1) improving the legal regulation of transport development taking into account the best European experience (making appropriate changes to the National Transport Strategy of Ukraine for the period up to 2030, forming the concept of inland water transport development, application of principles and tools of green economy);

2) the management of material and technical supply (calculation of the optimum volume of batch supply of material resources, optimization of procurement strategy of the enterprise, improving the management of the procurement process by multi-criteria evaluation of the choice of the optimum supplier of material resources);

3) the inventory management (analysis of inventory volumes in the warehouse, forecasting of the inventory volumes, formation of optimum inventory 
management strategy, development of inventory management system at enterprise, optimization of the volume of production, warehouse, and commodity inventory);

4) traffic management (implementation of cargo management information systems, application of automated processing of documents on completion of transportation of goods, development of proposals to optimize the load of transport, use of Internet technology for automation of transport processes);

5) management of customer service processes (analysis of the volume of shipment of products, forecasting of volumes of shipment of products to consumers, development of algorithms for servicing different categories of consumers, development of proposals to improve the level of logistic services);

6) sales activity management (rationale for the use of a network approach to the organization of sales activities of enterprises, formation of a system of contractual relationships with consumers, improvement of customer-oriented approach to the service of different categories of consumers in the context of the concept of relationship marketing, mechanism of implementation of public-private partnership in the management of sales activities of enterprises on the basis of the legal form of syndicate, methodical approach to the selection of the optimum sales channel of the finished product, identification of priority areas of e-commerce development as an effective tool for product promotion in the market);

7) information support of the organization of processes of logistic activity on the basis of the use of modern digital technologies.

Implementation of the above measures will contribute to the competitiveness of enterprises as a result of improving the management of logistic activities and standardization technology by reducing the time of execution of orders, reduction of inventory volumes, growth in the level of demand satisfaction and quality of logistic services, cost minimization, optimization of the material, transport, information, and financial flows, increase in the level of profitability of operating activities.

\section{Conflicts of Interest}

The authors declare no conflicts of interest regarding the publication of this paper.

\section{References}

Amosha, O. I., Drachuk, Yu. Z., Zaloznova, Y. S., et al. (2017). Application of Public-Private Partnership in the Field of Innovative Development of the Coal Industry. Collective Monograph, Institute of Industrial Economics of NAS of Ukraine. (in Ukrainian)

Andrienko, N. N., \& Syuechen, Z. (2020). Organizational and Economic Principles of Managing the Competitiveness of Transport Enterprises. Scientific Notes of the Tauride National University Named after V. I. Vernadsky. Series: Economics and Management, 31, 97-100. 
Belyaeva, E., \& Drachuk, Y. Z. (2018). Environmental Safety in the Management of Business Processes of Entrepreneurial Structures in Maritime Transport. In Proceeding of Scientific-Practical Conference "Problems of Enterprise Potential Development in Global Economic Conditions" (pp. 5-6). NAU. (in Russian)

Belyaeva, E., Kononov, A., \& Terzi, L. (2020). Business Processes Standardization in Logistics. 9th Scientific and Practical Symposium of Students and Young Scientists "Problems and Prospects of Transport Development", Odessa, 23 April 2020, 129-130. (in Ukrainian)

Brdulak, H., \& Michniewska, K. (2009). Zielona logistyka, ekologistyka, zrownowa zony rozwoj w logistyce. Koncepcje i strategie logistyczne. Logistyka, 4, 8-15.

Christof, Dr., \& Ehrhart, E. (2012). Delivering Tomorrow: Towards Sustainable Logistics. Deutsche Post AG.

Ćirović, G., Pamučar, D., \& Božanić, D. (2014). Green Logistic Vehicle Routing Problem: Routing Light Delivery Vehicles in Urban Areas Using a Neuro-Fuzzy Model. Expert Systems with Applications, 41, 4245-4258. https://doi.org/10.1016/j.eswa.2014.01.005

Dekker, R., Bloemhof, J., \& Mallidis, I. (2012). Operations Research for Green Logistics-An Overview of Aspects, Issues, Contributions and Challenges. European Journal of Operational Research, 219, 671-679. https://doi.org/10.1016/j.ejor.2011.11.010

Demidenko, V. V. (2015). Business Process Management as a Component of the Process Approach to Enterprise Management. Efficient Economy, No. 11, 1-6.

http://www.economy.nayka.com.ua/?op $=1 \& \mathrm{z}=4517$ (in Ukrainian)

Dźwigoł, H., Kwilinski, A., \& Trushkina, N. (2021). Green Logistics as a Sustainable Development Concept of Logistics Systems in a Circular Economy. Proceedings of the 37th International Business Information Management Association (IBIMA), Cordoba, 1-2 April 2021, 10862-10874.

Dźwigoł, H., Trushkina, N., \& Kwilinski, A. (2021). The Organizational and Economic Mechanism of Implementing the Concept of Green Logistics. Virtual Economics, 4, 74-108.

Harris, I., Mumford, C. L., \& Naim, M. M. (2014). A Hybrid Multi-Objective Approach to Capacitated Facility Location with Flexible Store Allocation for Green Logistics Modeling. Transportation Research Part E: Logistics and Transportation Review, 66, 1-22. https://doi.org/10.1016/j.tre.2014.01.010

Horohov, V. S. (2017). Standardization as a Tool for Business Processes Optimization at Commercial Enterprises. The Effectiveness of Public Administration, 1, 268-277.

Hryhorak, M. Y., \& Trushkina, N. V. (2020). Development of the Logistics System of the Economic Region "Polissya” in the Context of the Green Economy: Ecological Problems and Perspectives". Intellectualization of logistics and Supply Chain Management, 4, 27-40. https://doi.org/10.46783/smart-scm/2020-4-3

Janbo, L., \& Songxian, L. (2008). The Form of Ecological Logistics and Its Relationship Under the Globalization. Ecological Economy, 4, 290-298.

Jedliński, M. (2014). The Position of Green Logistics in Sustainable Development of a Smart Green City. Procedia - Social and Behavioral Sciences, 151, 102-111. https://doi.org/10.1016/j.sbspro.2014.10.011

Khaletska, A. (2015). Improvement of State Regulation of the Development of Transport Support in the Context of Simplification of Foreign Trade Procedures. Mechanisms of Public Administration. State Administration and Local Self-Government, 3, 199-206.

Koev, S. R., Tryfonova, O., Inzhyievska, L., Trushkina, N., \& Radieva, M. (2019). Management of Domestic Marketing of Service Enterprises. IBIMA Business Review, 2019, 


\section{1-13. https://doi.org/10.5171/2019.681709}

Krikavskij, E. (2017). On Standardization of Logistics Activities in Ukraine. Quality Management in Education and Industry: Experience, Problems and Prospects: $A b$ stracts of the III International Scientific and Practical Symposium. Lviv Polytechnic. (in Ukrainin)

Lai, K., \& Wong, C. W. (2012). Green Logistics Management and Performance: Some Empirical Evidence from Chinese Manufacturing Exporters. Omega, 40, 267-282. https://doi.org/10.1016/j.omega.2011.07.002

McKinnon, A., Browne, M., Whiteing, A., \& Piecyk, A. (2010). Green Logistics. Improving the Environmental Sustainability of Logistics (3nd ed.). Published by Kogan Page.

Mesjasz-Lech, A. (2011). Efektywnosc okonomiczna i sprawnosc ekologiczna logistyki zwrotnei (pp. 43-46). Published by Technical University of Czestochowa.

National Transport Strategy of Ukraine until 2030 (2021). https://zakon.rada.gov.ua/laws/show/430-2018-\%D1\%80?lang=en\#Text (in Ukrainian)

Polinkevich, A. N. (2014). Mechanisms of Business Processes Adaptation of Industrial Enterprises to the New Economy. Lutsk National Technical University. (in Ukrainian)

Sandiuk, H., Lushpiienko, Y., Trushkina, N., Tkachenko, I., \& Kurganskaya, E. (2019). Special Procedures for Electronic Public Procurement. Journal of Legal, Ethical and Regulatory, 22, 1-6.

https://www.abacademies.org/articles/Special-procedures-for-electronic-public-procur ement-1544-0044-22-SI-2-351.pdf

Sav'yuk, L. A., \& Drachuk, Y. Z. (2018). Business Processes in the Scientific and Industrial Sphere in the Conditions of the Knowledge Economy Formation. In Proceeding of Scientific-Practical Conference "Problems of Enterprise Potential Development in Global Economic Conditions" (pp. 57-58). NAU.

Sbihi, A., \& Eglese, R. W. (2009). Combinatorial Optimization and Green Logistics. Annals of Operations Research, 175, 159-175. https://doi.org/10.1007/s10479-009-0651-z

Seroka-Stolka, O. (2014). The Development of Green Logistics for Implementation Sustainable Development Strategy in Companies. Procedia-Social and Behavioral Sciences, 151, 302-309. https://doi.org/10.1016/j.sbspro.2014.10.028

Shulyar, R. V. (2019). Formation and Development of Economic and Managerial Tools for Ensuring Business Processes. Lviv Polytechnic National University. (in Ukrainian)

Sil'chuk, T. V. (2014). International Standards for Project Management in the Public Sector. Public Administration: Theory and Practice, 1, 75-79.

http://nbuv.gov.ua/UJRN/Pubupr_2014_1_13

Trushkina, N., \& Rynkevych, N. (2019). Optimization of Information Flows in Transport Logistics. In T. Pokusa, \& O. Nestorenko (Eds.), Contemporary Issues of Sustainable Development (pp. 137-146). The Academy of Management and Administration in Opole. (in Russian)

Trushkina, N. (2019a). Transformation of Customer Relationship Management in the Digital Economy. In T. Nestorenko, M. Wierzbik-Strońska (Eds.), Digital Economy and Digital Society: Monograph (pp. 311-316). Wydawnictwo Wyzszej Szkoly Technicznej w Katowicach. (in Russian)

Trushkina, N. V. (2019b). Transformation of the Transport and Logistics System in Ukraine on the Basis of Green Logistics. Economic Herald of the Donbas, 2, 151-161. (in Ukrainian) https://doi.org/10.12958/1817-3772-2019-2(56)-151-161

Trushkina, N. V. (2019c). Green Logistics as a Concept of Sustainable Development of 
the Transport and Logistics System in Ukraine. In V. Khrapkina, \& V. Ustymenko (Eds.), Determinants of Sustainable Economic Development: Monograph (pp. 232-241). Interservice. (in Ukrainian)

Trushkina, N. V., Drachuk, Y. Z., \& Zaloznova, Y. S. (2016). Logistics Concepts at the Industrial Enterprise under Conditions of the Globalization of Markets. Problems of Economy, 3, 228-238. (in Ukrainian)

Tryfonova, O., \& Trushkina, N. (2019). Application of Information Technologies in Logistic Activities of Enterprises. Conceptual Aspects Management of Competitiveness the Economic Entities: Collective Monograph (pp. 161-172). WSSG.

Ubeda, S., Arcelus, F., \& Faulin, J. (2011). Green Logistics at Eroski: A Case Study. International Journal of Production Economics, 131, 44-51.

https://doi.org/10.1016/j.ijpe.2010.04.041

Yakimishin, L. Y. (2015). Business Processes Reconstruction in the Supply Chain in the Context of Outsourcing. Economics and Enterprise Management, 1, 4-9. https://doi.org/10.15587/2312-8372.2015.36006

Zaloznova, Y. S., \& Trushkina, N. V. (2018a). Logistic Activities of Enterprises in Ukraine: Current State, Problems and Prospects. In Yu. Pasichnyk (Ed.), Sozioökonomische und rechtliche Faktoren der sozialen Entwicklung unter den Bedingungen der Globalisierung: Kollektive Monographie in 2 Bänden (pp. 253-268). Band 2. Shioda $\mathrm{GmbH}$. (in Russian)

Zaloznova, Y., \& Trushkina, N. (2018b). Mechanism for Providing Sustainable Development of Transport Infrastructure in Ukraine. In M. Bezpartochnyi (Ed.), Transformational Processes the Development of Economic Systems in Conditions of Globalization: Scientific Bases, Mechanisms, Prospects: Collective Monograph (pp. 43-53). Landmark SIA.

Zaloznova, Y., \& Trushkina, N. (2019). Management of Logistic Activities as a Mechanism for Providing Sustainable Development of Enterprises in the Digital Economy. Virtual Economics, 2, 63-80. https://doi.org/10.34021/ve.2019.02.01(4)

Zhang, S., Lee, C., Chan, H., et al. (2015). Swarm Intelligence Applied in Green Logistics: A Literature Review. Engineering Applications of Artificial Intelligence, 37, 154-169. https://doi.org/10.1016/j.engappai.2014.09.007 